\title{
Individual and population indicators of Zostera japonica respond quickly to experimental addition of sediment-nutrient and...
}

Article in Marine Pollution Bulletin · September 2016

DOI: 10.1016/j.marpolbul.2016.08.084

CITATIONS

0

5 authors, including:
READS

82

Laura M. Soissons

NIOZ Royal Netherlands Institute for Sea Res...

7 PUBLICATIONS 9 CITATIONS

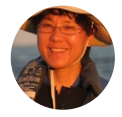

Dongyan Liu

East China Normal University

175 PUBLICATIONS $\quad 2,674$ CITATIONS

SEE PROFILE

SEE PROFILE

\section{Marieke M van Katwijk}

Radboud University

112 PUBLICATIONS 2,643 CITATIONS

SEE PROFILE

\section{Tjeerd J Bouma}

NIOZ Royal Netherlands Institute for Sea Res...

272 PUBLICATIONS 6,259 CITATIONS

SEE PROFILE

Some of the authors of this publication are also working on these related projects: 


\title{
Individual and population indicators of Zostera japonica respond quickly to experimental addition of sediment-nutrient and organic matter
}

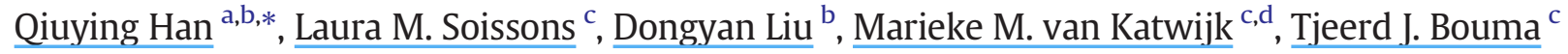 \\ a Hainan Tropical Ocean University, Sanya, Hainan, 572022, PR China

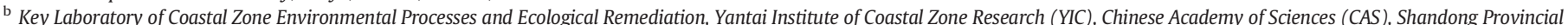 \\ Key Laboratory of Coastal Zone Environmental Processes, YICCAS, Yantai, Shandong, 264003, PR China \\ c Spatial Ecology Department, Royal Netherlands Institute for Sea Research (NIOZ-Yerseke), P.O. Box 140, 4400 AC Yerseke, The Netherlands

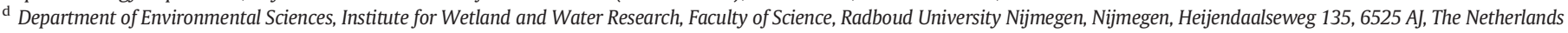

\section{A R T I C L E I N F O}

\section{Article history:}

Received 5 July 2016

Received in revised form 26 August 2016

Accepted 30 August 2016

Available online $\mathrm{xxxx}$

\section{Keywords:}

Seagrass

Indicators

Nutrient

Organic matter

Sediment dynamics

\begin{abstract}
A B S T R A C T
A manipulative field experiment was designed to investigate the effects of sediment-nutrients and sediment-organic matters on seagrasses, Zostera japonica, using individual and population indicators. The results showed that seagrasses quickly responded to sediment-nutrient and organic matter loading. That is, sediment-nutrients positively impacted on seagrasses by increasing $\mathrm{N}$ content of leaves and roots, leaf length and belowground biomass. Sediment-organic matter loading lowered $\mathrm{N}$ content of seagrass leaves and belowground biomass. Negative effects of organic matter loading were aggravated during nutrient loading, by decreasing $\mathrm{N}$ content of leaves, $\mathrm{P}$ content of roots, leaf width, shoot number in the middle period of the experiment, increasing $\mathrm{C} / \mathrm{N}$ ratio of leaves, $\mathrm{C} / \mathrm{P}$ and N/P ratio of roots and above to belowground biomass ratio of seagrasses. Consequently, Z japonica could be considered as a fast indicator to monitor seagrass ecosystem status in the eutrophic areas and facilitate to interpreting the response of seagrasses to multiple stressors.
\end{abstract}

(c) 2016 Elsevier Ltd. All rights reserved.

\section{Introduction}

Eutrophication, defined as an increased in the rate of organic matter supply to an ecosystem (Nixon, 1995; Nixon et al., 1996), is typically caused by an excess of nitrogen and phosphorus due to domestic sewage, agricultural fertilizers input, industrial wastes and marine aquaculture (Billen and Garnier, 2007; Bouwman et al., 2013; Gray et al., 2002 and its references). Seagrasses can provide important ecological services for the marine environment (Fourqurean et al., 2012; Hemminga and Duarte, 2000; Orth et al., 2006). In recent years, large-scale losses of seagrasses and risk of extinction for individual seagrass species were reported (Orth et al., 2006; Short et al., 2011). Eutrophication is identified as the main causes for the decline of seagrass meadows worldwide (Delgado et al., 1999; Govers et al., 2014; Orth et al., 2006; Waycott et al., 2009).

Seagrass plant community composition and the spatial distribution of individual species could vary with sediment organic content and nutrient (Barko and Smart, 1983 and its references; Burkholder et al., 2007). Seagrasses responses (e.g. shoot growth, density) to organic matter loading are species specific. Some species (e.g. Posidonia oceanica, Thalassia hemprichii, T. testudinum) showed less tolerance to

\footnotetext{
* Corresponding author.

E-mail address: qyhan@yic.ac.cn (Q. Han).
}

elevated organic matter content in the sediment than other seagrass species (e.g. Cymodocean nodosa and Zostera marina) (Holmer et al., 2005; Penhale and Wetzel, 1983; Pérez et al., 2007; Ruiz-Halpern et al., 2008; Terrados et al., 1999). Sulphide may accumulate due to the anaerobic decomposition of elevated organic matter, accelerating the mortality of seagrasses (Holmer and Kristensen, 1996; Pérez et al., 2007). Oxygen requirements of seagrass roots and rhizomes fully depend on oxygen transport from the leaves during such anoxic conditions (Smith et al., 1984), which may alter carbon, nitrogen and phosphorus metabolism of seagrass tissues (López et al., 1995; Mateo and Romero, 1997; Pregnall et al., 1984).

Nutrients can differently impact seagrasses depending on their concentration (Burkholder et al., 2007; Huntington and Boyer, 2008; van Katwijk et al., 1997). In oligotrophic areas, nutrient loading could have positive effects on seagrass growth (Burkholder et al., 2007; Lee and Dunton, 1997). In eutrophic areas, enriched nutrients can result in seagrasses mortality mainly due to nitrate and ammonia toxicity (Burkholder et al., 1992; Huntington and Boyer, 2008; van Katwijk et al., 1997). Nutrient enrichment can significantly increase N and P content of seagrass tissues (Bulthuis and Woelkerling, 1981; Invers et al., 2004), also decrease carbon reserves of seagrass tissues because $\mathrm{N}$ assimilation requires energy and $\mathrm{C}$ skeletons, further affect seagrass survival (Invers et al., 2004). Sediment-nutrient can increase leaf length of Halodule uninervis, and cause $H$. ovalis leaves to become longer, wider and thicker (La Nafie et al., 2013). 


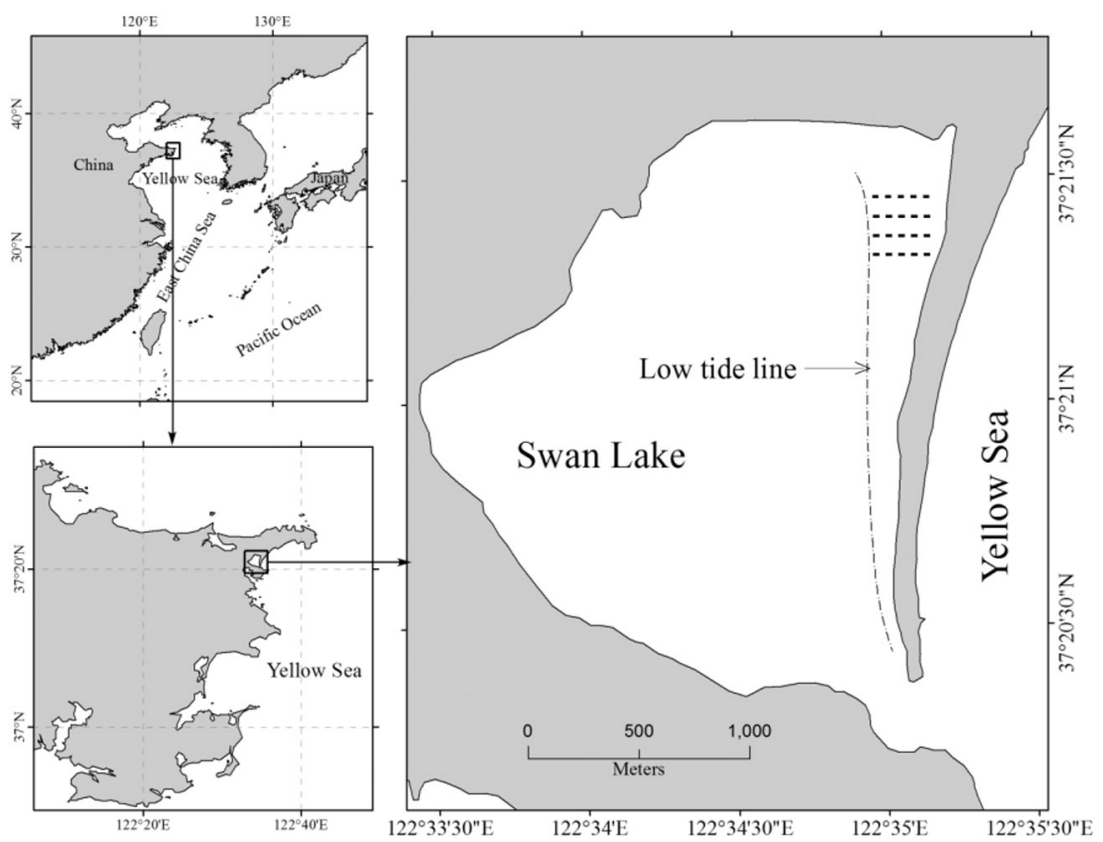

Fig. 1. Map showing field experimental location.

The individual effects of high nutrient and organic matter enrichment on seagrasses are generally well studied, whereas studies on the combined effects of multiple stressors on seagrasses are relatively rare (but see Govers et al., 2014; Pérez et al., 2007). Pérez et al. (2007) found organic matter and nutrient increased seagrasses mortality and decreased biomass of seagrasses. Govers et al. (2014) studied the effect of organic matter and nutrient in the sediment on the patch of Zostera noltii, concluding that patch survival and expansion are constrained at high loads of nutrients or organic matter as a result of porewater ammonium or sulphide toxicity.

Table 1

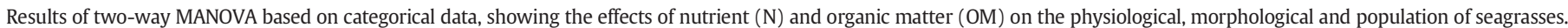
Univariate responses are shown as mean per treatment $\pm \mathrm{SE}$, with (mean (SE)), to show an indication of the strength of the response, $p$-values are included in the table.

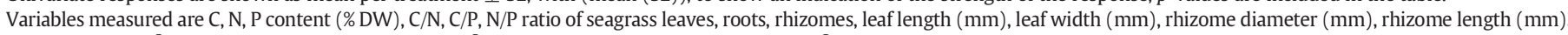

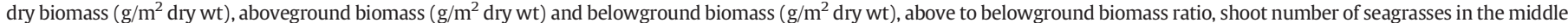
and end of experiment $\left(/ \mathrm{m}^{2}\right)$.

\begin{tabular}{|c|c|c|c|c|c|c|c|}
\hline \multirow[t]{2}{*}{ Variables } & \multirow[t]{2}{*}{ NN-NO } & \multirow[t]{2}{*}{ NN-HO } & \multirow[t]{2}{*}{ HN-NO } & \multirow[t]{2}{*}{$\mathrm{HN}-\mathrm{HO}$} & \multicolumn{3}{|l|}{$p$-Value } \\
\hline & & & & & $\mathrm{N}$ & $\mathrm{OM}$ & $\mathrm{N} \& \mathrm{OM}$ \\
\hline$C$ of leaf & $26.9(0.5)$ & $24.3(3.5)$ & $26.4(1.1)$ & $26.0(1.1)$ & 0.603 & 0.202 & 0.366 \\
\hline$C$ of root & $23.7(2.1)$ & $24.7(5.9)$ & $24.9(0.4)$ & $25.1(3.5)$ & 0.711 & 0.807 & 0.850 \\
\hline C of rhizome & $23.9(0.3)$ & $27.6(5.0)$ & $25.5(2.0)$ & $25.7(1.4)$ & 0.930 & 0.253 & 0.318 \\
\hline $\mathrm{N}$ of leaf & $2.2(0.1)$ & $2.0(0.3)$ & $2.4(0.1)$ & $2.1(0.1)$ & $0.070^{*}$ & $0.046^{* *}$ & 0.659 \\
\hline $\mathrm{N}$ of root & $1.5(0.1)$ & $1.6(0.1)$ & $1.7(0.1)$ & $1.6(0.1)$ & $0.035^{* *}$ & 0.887 & 0.110 \\
\hline $\mathrm{N}$ of rhizome & $1.2(0.1)$ & $1.5(0.3)$ & $1.6(0.3)$ & $1.4(0.1)$ & 0.236 & 0.911 & $0.068^{*}$ \\
\hline P of leaf & $0.81(0.17)$ & $1.39(0.97)$ & $1.34(0.64)$ & $1.37(0.29)$ & 0.488 & 0.412 & 0.452 \\
\hline P of root & $0.28(0.15)$ & $0.40(0.08)$ & $0.55(0.15)$ & $0.33(0.04)$ & 0.178 & 0.474 & $0.030^{* *}$ \\
\hline P of rhizome & $0.52(0.09)$ & $1.06(0.38)$ & $1.26(0.74)$ & $0.36(0.09)$ & 0.929 & 0.476 & $0.019^{* *}$ \\
\hline $\mathrm{C} / \mathrm{N}$ of leaf & $12.4(0.4)$ & $12.1(0.3)$ & $11.1(0.4)$ & $12.1(0.4)$ & 0.511 & 0.705 & $0.013^{* *}$ \\
\hline $\mathrm{C} / \mathrm{N}$ of root & $16.2(0.9)$ & $15.6(2.5)$ & $14.4(0.9)$ & $15.5(2.0)$ & 0.464 & 0.827 & 0.410 \\
\hline $\mathrm{C} / \mathrm{N}$ of rhizome & $20.5(0.3)$ & $18.8(1.0)$ & $15.8(2.5)$ & $19.0(2.4)$ & 0.532 & 0815 & $0.049^{* *}$ \\
\hline $\mathrm{C} / \mathrm{P}$ of leaf & $34.3(7.8)$ & $24.7(16.1)$ & $24.1(13.9)$ & $19.5(3.4)$ & 0.276 & 0.315 & 0.715 \\
\hline $\mathrm{C} / \mathrm{P}$ of root & $106.0(56.5)$ & $63.6(24.2)$ & $47.6(13.7)$ & $78.2(18.4)$ & 0.281 & 0.765 & $0.090^{*}$ \\
\hline $\mathrm{C} / \mathrm{P}$ of rhizome & $47.3(10.0)$ & $27.4(5.9)$ & $27.2(19.6)$ & $75.1(20.0)$ & 0.153 & 0.148 & $0.005^{* * *}$ \\
\hline N/P of leaf & $2.7(0.5)$ & $2.0(1.3)$ & $2.2(1.4)$ & $1.6(0.3)$ & 0.418 & 0.292 & 0.919 \\
\hline $\mathrm{N} / \mathrm{P}$ of root & $6.4(3.2)$ & $4.0(1.1)$ & $3.3(1.0)$ & $5.0(0.7)$ & 0.335 & 0.733 & $0.083^{*}$ \\
\hline $\mathrm{N} / \mathrm{P}$ of rhizome & $2.3(0.5)$ & $1.5(0.2)$ & $1.9(1.6)$ & $3.9(0.6)$ & $0.092^{*}$ & 0.306 & $0.026^{* *}$ \\
\hline Leaf length & $71.3(14.7)$ & $65.6(10.4)$ & $93.0(15.8)$ & $91.2(17.2)$ & $0.053^{*}$ & 0.311 & 0.768 \\
\hline Leaf width & $1.5(0.2)$ & $1.4(0.2)$ & $1.8(0.2)$ & $1.5(0.2)$ & 0.303 & 0.316 & 0.248 \\
\hline Rhizome diameter & $1.4(0.1)$ & $1.3(0.1)$ & $1.5(0.1)$ & $1.3(0.2)$ & 0.424 & 0.539 & 0.469 \\
\hline Rhizome length & $15.3(2.4)$ & $16.6(3.4)$ & $13.6(6.0)$ & $14.2(12.0)$ & 0.116 & 0.252 & 0.905 \\
\hline Dry biomass & $16.7(1.9)$ & $10.2(5.6)$ & $21.0(11.8)$ & $19.6(5.7)$ & 0.218 & 0.353 & 0.395 \\
\hline Aboveground biomass & $11.6(1.6)$ & $6.7(3.4)$ & $15.1(8.4)$ & $15.0(4.4)$ & 0.241 & 0.485 & 0.313 \\
\hline Belowground biomass & $5.1(1.3)$ & $3.5(2.2)$ & $5.9(3.6)$ & $4.5(2.0)$ & $0.086^{*}$ & $0.055^{*}$ & 0.907 \\
\hline Above to belowground biomass ratio & $2.4(0.8)$ & $2.2(0.6)$ & $2.6(0.4)$ & $3.6(1.1)$ & 0.418 & 0.638 & $0.099^{*}$ \\
\hline Shoot number in the middle period of experiment & $109(31)$ & $111(49)$ & $142(50)$ & $97(48)$ & 0.763 & 0.529 & 0.263 \\
\hline Shoot number in the end of the experiment & $977(233)$ & $586(307)$ & $1161(746)$ & $1036(381)$ & 0.144 & 0.229 & 0.526 \\
\hline
\end{tabular}

$* p<0.1$.

** $p<0.05$

*** $p<0.01$ 
Higher nitrogen and organic matter contents in sediments contribute to the sediment denitrification (Zhang et al., 2012). Denitrification may be heterotrophic, with organic substrates as energy source, with reduced inorganic compounds such as sulfur or iron used as electron donors (Korom, 1992), which was energy source for anaerobic respiratory processes. Anaerobic environment may promote sediment denitrification (Baker et al., 2000; Zhang et al., 2012 and its references). Nutrient enrichment may further intensify the flux of organic matter to the sediment, thereby enhancing the risk of anoxia and sulphide toxicity (Borum et al., 2005; Holmer and Bondgaard, 2001; Olivé et al., 2009; Pérez et al., 2007). High organic matter content may also enhance the process of nitrate transformed into ammonium (Seitzinger, 1988), consequently increase ammonium toxicity to seagrasses (Govers et al., 2014). The ecological significance of this process in high nutrient and organic matter loading areas is three-folds: firstly, organic matter may negatively impact on seagrasses due to hypoxia; Secondly, organic matter may decrease the impact of nutrient loading on seagrasses; Thirdly, nutrient loading may aggravate the negative effects of elevated organic matter on seagrasses. To our knowledge, there are no studies on the effects of elevated organic matter loading in the sediments during high nutrient enrichment on the individual (physiology, morphology) and population parameters of small seagrasses (e.g. Zostera japonica). This is a relevant subject because a better understanding of the eutrophic process is needed to reflect the impacts on seagrasses from a
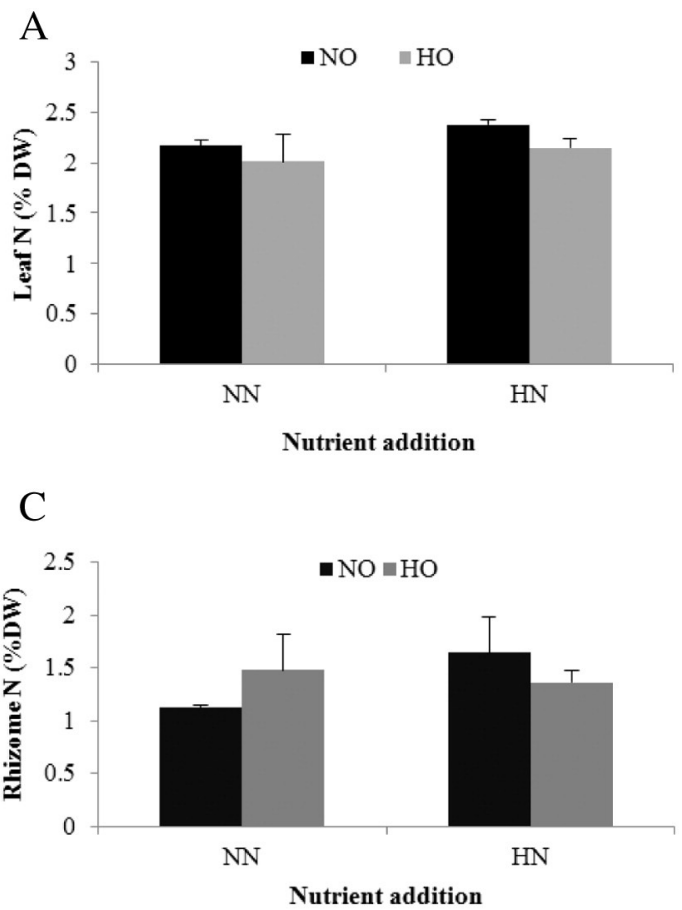

E

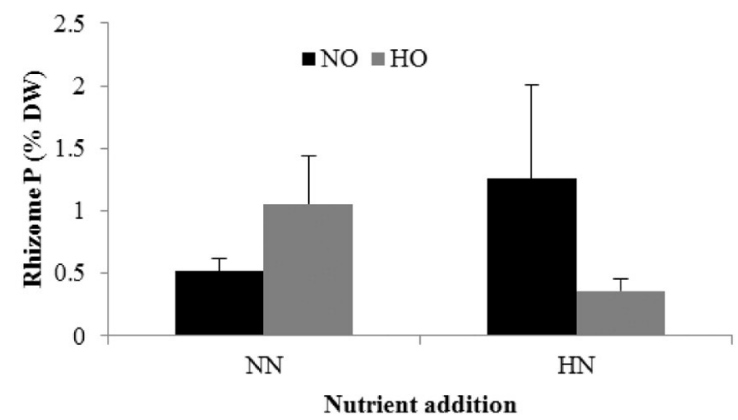

combination of anthropogenic pressures, therefore improve our management capacity.

Consequently, we hypothesize that increased nutrients loading will lead to the negative effects of organic matter to seagrasses by increasing competition for oxygen and resulting in hypoxia within seagrasses, although we expect nutrients may contribute seagrass growth. We therefore carried out a short term (five weeks) manipulative field experiment to test if elevated nutrient enhance the expected adverse effect of organic matter on the seagrass Zostera japonica, in the sediments creating gap disturbances, using two level indicators: individual (physiology and morphology) and population. Physiological parameters (C, $N$ and $P$ content of seagrass tissues) were reported to be good indicators of saturating nutrient supply to an environment (e.g. Burkholder et al., 2007; Fourqurean and Zieman, 1992; Fourqurean et al., 1997; Pérez et al., 2008; van Katwijk et al., 2011). Seagrass morphological characteristics (e.g. leaf length, leaf width, rhizome diameter, rhizome length) can be used as indicators in nutrient enrichment (e.g. Burkholder et al., 2007; Lee et al., 2004). Population level indicators (e.g. population biomass, shoot density) could represent characteristic imprints of environmental conditions (e.g. Hauxwell et al., 2001; Hessing-Lewis et al., 2011; Martínez-Crego et al., 2008; Wood and Lavery, 2000). We did a short term manipulative experiment because small seagrasses may rapidly recover by clonal growth after modest sediment disturbance (Han et al., 2012; La Nafie et al., 2013). Moreover, we aim to search good
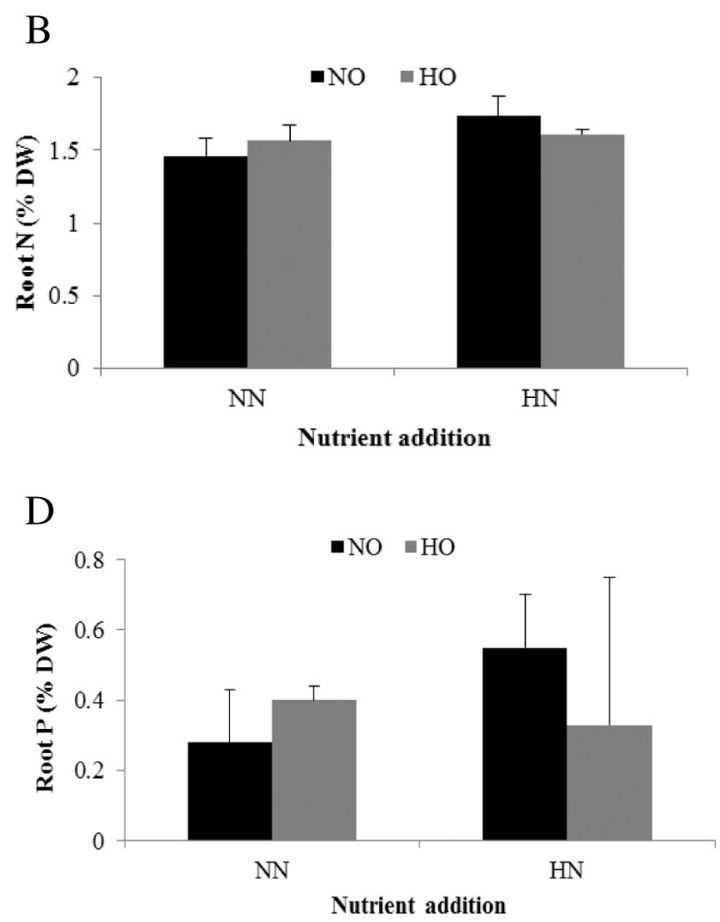

Fig. 2. Seagass tissues nitrogen $(\mathrm{N})$ and phosphate $(\mathrm{P})$ content responses to sediment nutrient and organic matter influence. Significances see Tables 1 and 2. 
indicators to show the effects of higher organic matter loading and nutrient enrichment in the short term disturbances, which will provide useful insights for seagrass management, protection and restoration in the situation of nutrient and organic matter enriched areas such as typical areas along the coast of China.

\section{Materials and methods}

\subsection{Field experimental location and design}

Swan lake $\left(\mathrm{N} 36^{\circ} 43^{\prime}-37^{\circ} 27^{\prime}, \mathrm{E} 122^{\circ} 09^{\prime}-122^{\circ} 42^{\prime}\right)$, a shallow coastal lagoon, is located in the eastern part of Shandong peninsula, northern Yellow Sea of China (Fig. 1). There are Zostera japonica and $Z$. marina seagrass meadows throughout the lake (Dong et al., 2007). Although Z. japonica seagrass population showed increasing trend worldwide (Short et al., 2011), it is declining in northern China coast (e.g. Swan Lake, Yellow River Delta) in recent years possibly due to human activities (Han et al., 2016). Shellfish aquaculture, sewage discharge and swans feces can enhance high nutrient and organic matter loads into sediments within seagrass habitats, which may contribute to the decline of seagrasses, $Z$. japonica in Swan Lake. The dam construction (Zhang et al., 2014) and manual $R$. philippinarum collection during the low tide may disturb the sediment in seagrass meadow at a small scale, which could affect seagrass patch development.

An in situ manipulative experiment was conducted in Swan Lake to test the combined effects of sediment nutrient ("HN" = high nutrient addition, "NN" = no nutrient addition) and organic matter ("HO" = high organic matter addition, "NO" = no organic matter addition) (Fig. 1). The in situ experiment consisted of 3 treatments: i) sediment-nutrient enrichment (HN-NO), ii) sediment-organic matter enrichment (NN-HO) and iii) sediment-nutrient \& sediment-organic matter enrichment ( $\mathrm{HN}-\mathrm{HO}$ ) plus a control (NN-NO) (i.e., no sediment-nutrient enrichment and no sediment-organic matter enrichment). 5 plots per treatment plus 5 plots for control (20 plots in total) were set up. For preventing nutrient and organic matter cross-contamination, a minimum distance of $5 \mathrm{~m}$ between plots in the same treatment and a minimum distance of $35 \mathrm{~m}$ between different treatments were implemented. In Swan Lake, hydrodynamics are weak (Han et al., 2016). Our results showing nutrient and organic matter effects also supported sufficient independence between the treatments.

Experimental and control plots were selected in areas with the average Zostera japonica shoot density. At the beginning of the experiment, the cylinder (diameter $50 \mathrm{~cm}$, height $5 \mathrm{~cm}$ ) was placed within the meadows, and all seagrass materials (including aboveand belowground part) were collected to estimate total fresh biomass. Fresh biomasses were not differences among treatments $(F=2.098, p=0.141)$. In the newly created bare areas, fertilization was done using a slow-release commercial fertilizer $(\mathrm{g} / \mathrm{g}$ ratio $\mathrm{N}: \mathrm{P}: \mathrm{K}$; 26:11:11; Osmocote). In each fertilized plot, $150 \mathrm{~g}$ Osmocote were added into the sediment of the plot for nutrient-enrichment, which was equal to $1500 \mathrm{~kg}$ per ha every year. In China coast, nutrient pollution could be more severe than before due to aquaculture and fertilizer used in agriculture (ART, 2006; Miao and Jiang, 2007), so we used higher nutrient loading in our manipulative experiment than other studies (e.g. Govers et al., 2014). Organic carbon content in the sediment is $0.66 \pm 0.19 \%$ naturally in seagrass meadows. $400 \mathrm{~g}$ organic matters (humic acid) were added into the sediment of the plot for organic matter-enrichment, showing about $0.7 \%$ more organic matter into sediment. Organic matter consisted of $4.43 \%$ moisture, $11.23 \%$ ash, $11.42 \%$ volatiles, $70.40 \%$ fixed carbon, $2.21 \%$ hydrogen and $0.31 \%$ sulfur. Nutrients and organic matters were mixed with sediments in the plot for sediment-nutrient \& sediment-organic matter enrichment.

\subsection{Sampling and measurement}

The experiment started in June 2012 and lasted for five weeks. In the middle and end of the experiment, shoot number in each plot was counted. All seagrass materials within the experimental plots were harvested in the end. Seagrass (leaves with rhizomes and roots) samples were collected using a spade (deep into $20 \mathrm{~cm}$ sediment) and then cleaned. All samples were kept in a refrigeration box and transported to the laboratory for measurement. The morphological characteristics of seagrasses (leaf length, leaf width, rhizome diameter, rhizome length) were measured within three days following the harvest, and then the seagrass samples were frozen and dried using the freezing dryer (Christ ALPHA 1-4 LD plus). Dry biomass of seagrasses was weighted in the laboratory. The above to belowground biomass ratio of seagrasses was also calculated. Lastly, the C, N and P contents (as \% of dry weight) of seagrass leaves, roots and rhizomes were analyzed. The $\mathrm{C}$ and $\mathrm{N}$ contents of seagrass tissues were analyzed using elemental analyser (Vario Macro cube, Elmentar Company, Germany). The total P content was determined by a dry-oxidation, acid hydrolysis extraction followed by a colorimetric analysis of phosphate concentration of the extract (Fourqurean and Zieman, 1992). C/N, C/P and N/P ratio of seagrass tissues was also calculated.

\subsection{Statistical analysis}

To test the effect of nutrient $(\mathrm{N})$ and organic matter $(\mathrm{OM})$, and their interaction $(\mathrm{N} \times \mathrm{OM}) \times \mathrm{OM})$ on individual indicators including physiological ( $\mathrm{C}, \mathrm{N}$ and $\mathrm{P}$ content, $\mathrm{C} / \mathrm{N}, \mathrm{C} / \mathrm{P}, \mathrm{N} / \mathrm{P}$ ratio in seagrass leaves, rhizomes and roots), morphological properties (leaf length, leaf width, rhizome diameter, rhizome length) and population indicators (shoot number in the middle and end of the experiment, dry biomass, aboveground biomass, belowground biomass and above to belowground ratio of seagrasses), we used a two-way ANOVA. The $p$-value of the

\section{Table 2}

Results of student's $t$-test between HN-NO and HN-HO treatments based on categorical data, showing the effects of organic matter on the physiological, morphological and population parameters of seagrasses mentioned in Table 1 during high nutrient loading. $p$ Values are included in the table.

\begin{tabular}{lll}
\hline Variables & $t$ & $p$ \\
\hline C of leaf & 0.523 & 0.629 \\
C of root & -0.058 & 0.956 \\
C of rhizome & -0.191 & 0.858 \\
N of leaf & 4.138 & $0.014^{* *}$ \\
N of root & 1.840 & 0.140 \\
N of rhizome & 1.341 & 0.251 \\
P of leaf & -0.066 & 0.950 \\
P of root & 2.586 & $0.061^{*}$ \\
P of rhizome & 2.085 & 0.105 \\
C/N of leaf & -3.074 & $0.037^{* *}$ \\
C/N of root & -0.897 & 0.421 \\
C/N of rhizome & -1.575 & 0.190 \\
C/P of leaf & 0.556 & 0.608 \\
C/P of root & -2.315 & $0.082^{*}$ \\
C/P of rhizome & -0.693 & 0.527 \\
N/P of leaf & 0.741 & 0.500 \\
N/P of root & -2.315 & $0.082^{*}$ \\
N/P of rhizome & -2.008 & 0.115 \\
Leaf length & 0.166 & 0.872 \\
Leaf width & 2.126 & $0.066^{*}$ \\
Rhizome diameter & 1.630 & 0.142 \\
Rhizome length & -0.089 & 0.931 \\
Dry biomass & 0.249 & 0.809 \\
Aboveground biomass & 0.027 & 0.980 \\
Belowground biomass & 0.747 & 0.476 \\
Above to belowground biomass ratio & -1.913 & $0.092^{*}$ \\
Shoot number in the middle period of experiment & 2.189 & $0.060^{*}$ \\
Shoot number in the end of the experiment & 0.332 & 0.748 \\
\hline$*$ p 0.1. & & \\
$* *$ p 0.05. & & \\
& & \\
\hline & & \\
\hline
\end{tabular}


univariate responses was used to indicate which of these separate variables gave the most significant response. Those data that deviated from normality (Kolmogorov-Smirnov's test) or homoscedasticity (Levene's test) were transformed prior to analyze to meet two-way ANOVA assumptions. The differences of seagrass parameters above-mentioned between $\mathrm{HN}-\mathrm{NO}$ and $\mathrm{HN}-\mathrm{HO}$ treatments were tested by a two-sample Student's $t$-test for independent samples to analyze organic matter effects during high nutrient loading. We set $p$ values as highly significant, significant, and marginally significant when $p=0.01,0.05$, and 0.1 , respectively (La Nafie et al., 2012; Soissons et al., 2014).

\section{Results}

\subsection{Physiological properties of seagrasses}

Nutrient marginally significantly and significantly increased $\mathrm{N}$ content of seagrass leaves and roots, respectively (Table 1; Fig. 2A, B). Organic matter significantly decreased $\mathrm{N}$ content of seagrass leaves (Table 1; Fig. 2A). Organic matter significantly decreased $\mathrm{N}$ content of

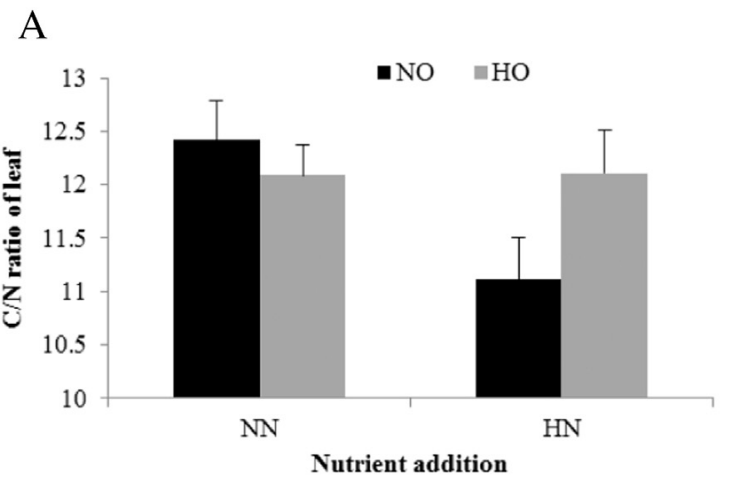

$\mathrm{C}$

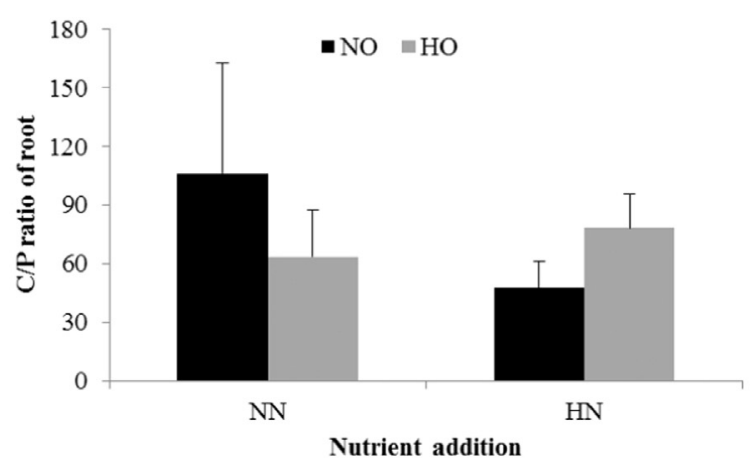

$\mathrm{E}$

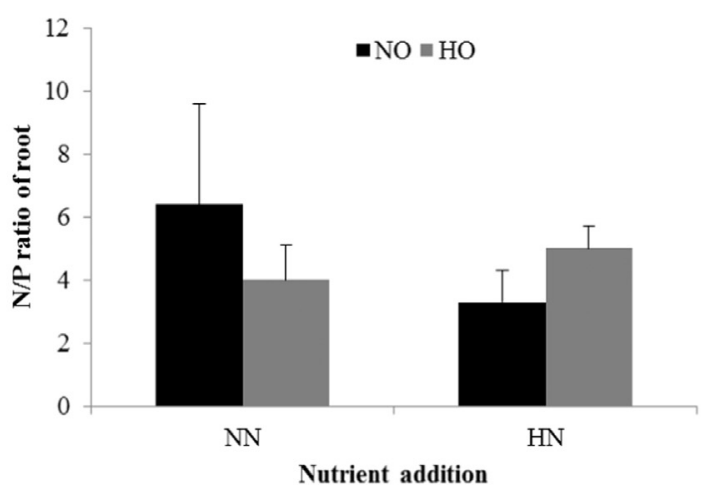

leaves in the conditions of nutrient loading (Table 2; Fig. 2A) $(t=$ $4.138, p=0.014)$. $\mathrm{N}$ content value of seagrass rhizomes was marginally significantly affected by the combination of organic matter and nutrient addition (Table 1; Fig. 2C). The lowest $\mathrm{N}$ content value $((2.0 \pm 0.3) \%)$ of seagrass leaves was observed in the $\mathrm{NN}-\mathrm{HO}$ treatments. The lowest $\mathrm{N}$ content value of seagrass roots $((1.5 \pm 0.1) \%)$ and rhizomes $((1.2 \pm$ $0.1) \%$ ) was observed in the control treatments (Table 1$)$. The highest $\mathrm{N}$ content value of seagrass leaves $((2.4 \pm 0.1) \%)$, roots $((1.7 \pm 0.1)$ $\%)$ and rhizomes $((1.6 \pm 0.3) \%)$ was found in the HN-NO treatments (Table 1).

Organic matter marginally significantly decreased $P$ content of roots in the conditions of nutrient loading $(t=2.586, p=0.061)$ (Table 2; Fig. 2D). P content of seagrass roots and rhizomes was significantly affected by the combination of organic matter and nutrient addition (Table 1 ; Fig. 2D, E). The highest $\mathrm{P}$ content value of seagrass roots $((0.55 \pm$ $0.15) \%)$ and rhizomes $((1.26 \pm 0.74) \%)$ was found in the HN-NO treatments (Table 1$)$. The lowest $\mathrm{P}$ content value of seagrass roots $((0.28 \pm$ $0.15) \%)$ and rhizomes $((0.36 \pm 0.09) \%)$ was separately recorded in the control and HN-HO treatments (Table 1).
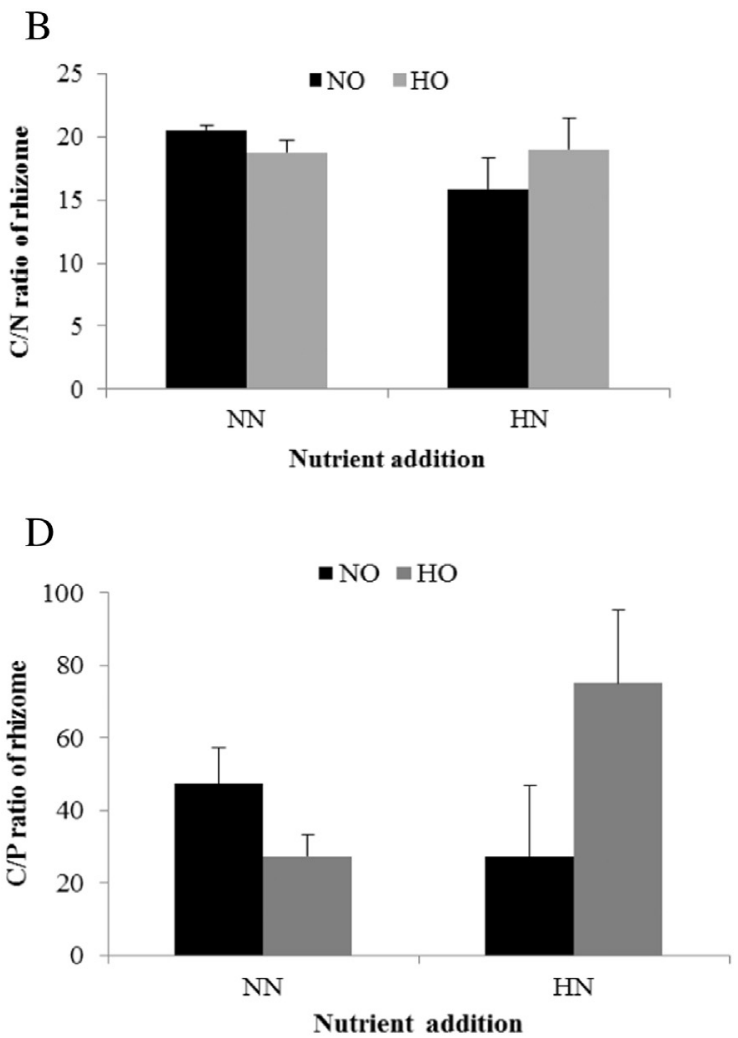

F

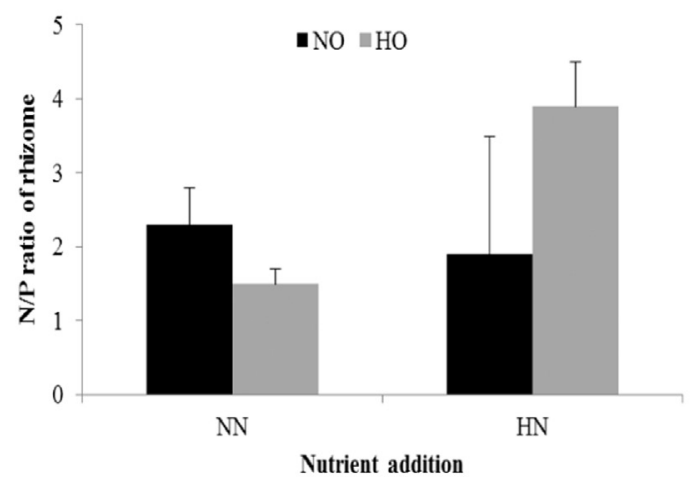

Fig. 3. Seagass tissues C/N, C/P, N/P ratio responses to sediment nutrient and organic matter influence. Significances see Tables 1 and 2. 
A

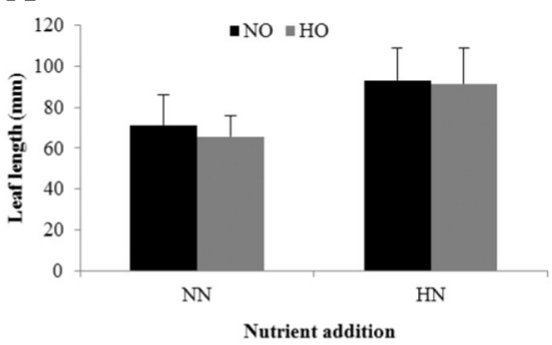

B

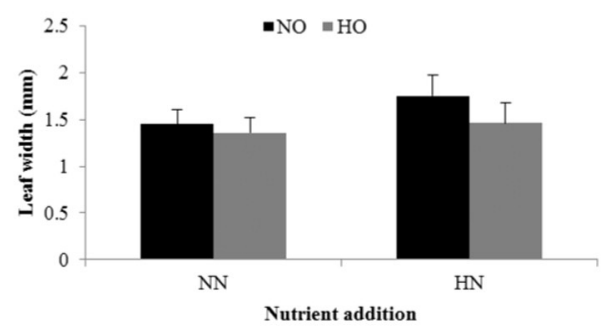

Fig. 4. Morphological characteristics of the seagrass plants responses to sediment nutrient and organic matter loading. Significances see Tables 1 and 2.

Organic matter significantly increased $\mathrm{C} / \mathrm{N}$ ratio of leaves in the conditions of nutrient loading (Table 2; Fig. 3A) $(t=-3.074, p=0.037) . \mathrm{C} /$ $\mathrm{N}$ ratio of leaves and rhizomes was significantly affected by the combination of organic matter and nutrient addition (Table 1; Fig. 3A, B). The lowest $\mathrm{C} / \mathrm{N}$ ratio value of seagrass leaves $((11.1 \pm 0.4) \%)$ and rhizomes $((15.8 \pm 2.5) \%)$ was observed in the HN-NO treatments (Table $1)$. The highest $\mathrm{C} / \mathrm{N}$ ratio value of seagrass leaves $((12.4 \pm 0.4) \%)$ and rhizomes $((20.5 \pm 0.3) \%)$ was recorded in the control treatments (Table 1).

Organic matter marginally significantly increased C/P ratio of roots in the conditions of nutrient loading (Table 2, Fig. $3 C)(t=-2.315$, $p=0.082$ ). C/P ratio of roots and rhizomes was respectively marginally and highly significantly affected by the combination of organic matter and nutrient addition (Table 1; Fig. 3C, D). The lowest C/P ratio value $((47.6 \pm 13.7) \%)$ of seagrass roots was observed in the HN-NO treatments, while the highest value $((106.0 \pm 56.5) \%)$ in the control treatments (Table 1$)$. The lowest $((27.2 \pm 19.6) \%)$ and highest $((75.1 \pm$ $20.0) \%$ ) C/P ratio values of seagrass rhizomes were separately found in the HN-NO and HN-HO treatments (Table 1).

Organic matter marginally significantly increased N/P ratio of roots in the conditions of nutrient loading (Table 2; Fig. 3E) $(t=-2.315$, $p=0.082)$. N/P ratio of roots and rhizomes was marginally and significantly affected by the combination of organic matter and nutrient addition, respectively (Table 1 ; Fig. $3 \mathrm{E}, \mathrm{F})$. The lowest N/P ratio value $((3.3 \pm$ $1.0) \%$ ) of seagrass roots was found in the HN-NO treatments, while the highest $((6.4 \pm 3.2) \%)$ in the control treatments (Table 1$)$. The lowest $((1.5 \pm 0.2) \%)$ and highest $((3.9 \pm 0.6) \%) \mathrm{N} / \mathrm{P}$ ratio values of seagrass rhizomes were separately found in the NN-HO and $\mathrm{HN}-\mathrm{HO}$ treatments (Table 1).

\subsection{Morphological properties of seagrasses}

Nutrient loading marginally significantly increased leaf length with the highest value $((93.0 \pm 15.8) \mathrm{mm})$ in the $\mathrm{HN}-\mathrm{NO}$ treatments (Table 1 ; Fig. 4A). Organic matter marginally significantly decreased leaf width in the conditions of nutrient loading $(t=2.126, p=0.066)$ (Table 2$)$, with the highest value $((1.8 \pm 0.2) \mathrm{mm})$ in the HN-NO treatments, while the lowest value $((1.4 \pm 0.2) \mathrm{mm})$ in the NN-HO treatments (Table 1; Fig. 4B).

\subsection{Population properties of seagrasses}

Nutrient loading marginally significantly increased belowground biomass of seagrasses, but which was marginally significantly decreased by organic matter loading (Table 1; Fig. 5A). No significant interaction effects were found. The highest belowground biomass value ( $5.9 \pm$ 3.6) $\mathrm{g} / \mathrm{m}^{2}$ dry wt) of seagrasses was recorded in the HN-NO treatments, while the lowest value $\left((3.5 \pm 2.2) \mathrm{g} / \mathrm{m}^{2}\right.$ dry wt $)$ in the NN-HO treatments (Table 1; Fig. 5A).
A

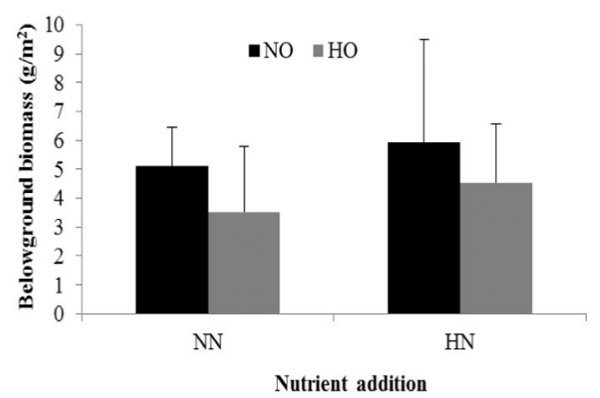

C

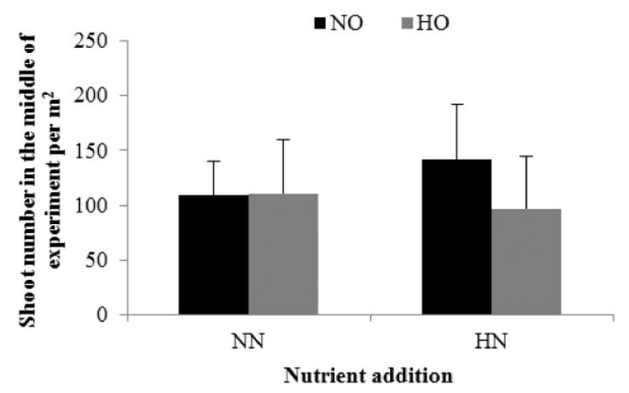

$\mathrm{B}$

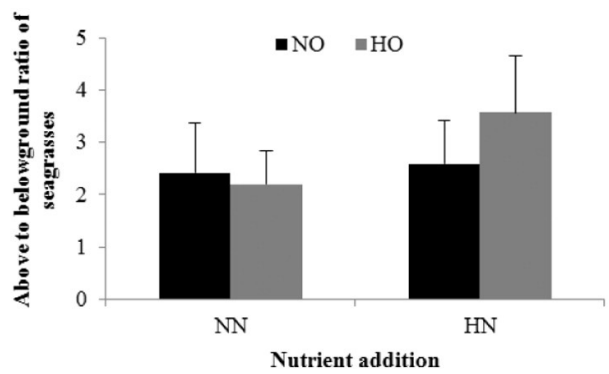

Fig. 5. Population characteristics of the seagrasses responses to sediment nutrient and organic matter loading. Significances see Tables 1 and 2. 
Above to belowground biomass ratio was marginally significantly increased by organic matter addition in the conditions of nutrient loading (Table 2; Fig. 5B) $(t=-1.913, p=0.092)$, which was marginally significantly affected by the combination of organic matter and nutrient addition with the highest value $(3.6 \pm 1.1)$ in the $\mathrm{HN}-\mathrm{HO}$ treatments, while the lowest value $(2.2 \pm 0.6)$ in the NN-HO treatments (Table 1 ; Fig. 5B).

Organic matter marginally significantly decreased shoot number of seagrasses in the middle period of experiment in the conditions of nutrient loading (Table 2; Fig. 5C) $(t=2.189, p=0.060)$, with the lowest value $(97 \pm 48)$ in the $\mathrm{HN}-\mathrm{HO}$ treatments, while the highest value $(142 \pm 50)$ in the HN-NO treatments (Table 1; Fig. 5C).

\section{Discussion}

Anthropic activity and global climate change can bring nutrients and organic matters into sediments, thereby alter characteristics of seagrasses (Pérez et al., 2007; Rabalais et al., 2009; Short and Wyllie-Echeverria, 1996). Our results showed that seagrasses quickly responded to sediment-nutrient and organic matter loading at individual and population levels. That is, sediment-nutrients positively impacted on seagrasses. Sediment-organic matter loading showed negative effects on seagrasses that was aggravated during high nutrient loading. This has to our knowledge, not previously been reported in seagrasses.

\subsection{Positive effects of sediment-nutrient enrichment on individual and pop-} ulation indicators of seagrasses

Plants exposed to high nutrient loads can show physiological change, such as increases in tissue nutrient content (Invers et al., 2004; Peterson et al., 2012; Pérez et al., 2007; Udy and Dennison, 1997a). In our study, $\mathrm{N}$ content of seagrass roots and rhizomes was lower than $1.8 \%$ of the dry weight (Table 1 ; Fig. 2B, C), indicating that these seagrasses were probably nutrient-limited at the start of the experiment (Duarte, 1990). In our study at the end of the experiment, nutrient loading significantly increased $\mathrm{N}$ content of seagrass leaves and roots (Table 1; Fig. 2A, B), which was in agreement with Peralta et al. (2003) from Zostera marina study. Seagrass roots can absorb nutrient from the porewater, and one-third nitrogen fixation activity in sediments was associated with below-ground part of seagrasses (Romero et al., 2006). Our results confirmed that $Z$. japonica roots may supply the $\mathrm{N}$ demand of seagrasses by transferring $\mathrm{N}$ to aboveground part in nutrient rich sediments, and $\mathrm{N}$ content of seagrass tissues could be used as a good indicator for sediment-nutrient loading.

Nutrient availability is reflected within seagrasses via increased growth (Peterson et al., 2012). In our study, sediment nutrient increased leaf length and belowground biomass of seagrasses, which indicated that nutrients are used for seagrasses growth (Short, 1983; Peterson et al., 2012). Previous studies also showed sediment nutrient fertilization increased leaves biomass (e.g. Hemminga and Duarte, 2000; La Nafie et al., 2013; Lee and Dunton, 1999; Peralta et al., 2003; Peterson et al., 2012). Nutrient availability may be incorporated into the carbohydrate reserves of seagrasses (e.g. Thalassia tesudinum) (Campbell et al., 2012). Respiration rates of seagrasses may enhance with increasing nutrient enrichment in the sediment (Touchette, 1999), which could help rhizomes and roots of seagrasses to supply the energy and carbon needed to assimilate and reduce nitrate, consequently decrease the toxicity of higher concentration nutrients, facilitate seagrass growth (Touchette, 1999; Touchette and Burkholder, 2000).

4.2. Negative effects of elevated organic matter on individual and population indicators of seagrasses during high nutrient loading

Organic matters significantly decreased $\mathrm{N}$ content of seagrass leaves (Tables 1, 2; Fig. 2A) and increased $\mathrm{C} / \mathrm{N}$ ratio of leaves in the conditions of nutrient loading (Tables 1, 2; Fig. 3A). It may be because organic matter can induce sediment redox in the conditions of nutrient loading, which reduces the absorption of seagrass roots to $\mathrm{N}$, especially nitrate available forms by denitrification from bacterial metabolism (Peralta et al., 2003; Udy and Dennison, 1997b; Worm and Reusch, 2000; Worm et al., 2000). In the conditions of higher nutrient loading, denitrification requires a supply of organic matter as energy source (Seitzinger and Nixon, 1985 and its references), resulting in anaerobic respiratory processes (Korom, 1992), which may conversely promote sediment denitrification (Baker et al., 2000; Zhang et al., 2012 and its references). Nutrients absorption of seagrass roots may impact on uptake of seagrass leaves to nitrogen (Thursby and Harlin, 1982, 1984). Also epiphyte overgrowth due to additive sediment-nutrient and organic matter loading may hinder $\mathrm{N}$ uptake by seagrass leaves, therefore decrease $\mathrm{N}$ uptake of seagrass leaves (Apostolaki et al., 2012; Balata et al., 2010; Cancemi et al., 2003; Delgado et al., 1999), although we did not observe epiphytes in this study.

Phosphate enrichment of the seagrass (e.g. Heterozostera tasmanica) sediments can increase P content in the rhizomes (from 0.16-0.18\%) (Bulthuis and Woelkerling, 1981). In our study, phosphate loading in the sediment did not significantly impact on P content of Zostera japonica tissues, because $\mathrm{P}$ content of seagrass tissues was above the threshold $(0.2 \%)$ for limitation for seagrasses outlined by Duarte (1990), indicating there is not P limited in our study area. Roots can assimilate phosphate from the porewater of sediment (Brix and Lyngby, 1985). Organic matter marginally significantly decreased $\mathrm{P}$ content of roots $(t=$ 2.586, $p=0.061$ ) (Table 2; Fig. 2D) and increased C/P and N/P ratio of roots in the conditions of nutrient loading (Table 2; Fig. 3C, E). That copes with Pérez et al. (2007), who found organic matter reduced P content of Posidonia oceanica. Plants require more P for higher growth rates (Ågren, 2004; Sterner and Elser, 2002), because P is required during the metabolic energy transfer process (Duarte, 1990; Stitt, 1997). Organic matter can result in low energy status of seagrasses (Erskine and Koch, 2000; Pérez et al., 2008), therefore negatively affect P uptake of seagrasses by increasing decomposition under low-oxygen conditions (Day et al., 1989; Pérez et al., 2007). Phosphate may play a key role in reducing ammonium toxicity (Brun et al., 2002, 2008). When carbon turnover and ATP consumption increase as a result of ammonium assimilation in the conditions of nutrient loading, an enhancement of phosphate demands would be expected (Brun et al., 2002; Villazán et al., 2013). Phosphate also easily adsorbs to organic particles during higher organic matter loading (Froelich, 1988; Stumm and Morgan, 1996). Consequently, high nutrient and organic matter loading process limiting phosphate availability and acquisition might make seagrasses more vulnerable to ammonium toxicity (Villazán et al., 2013).

Organic matter marginally significantly decreased leaf width, shoot number in the middle period of the experiment during nutrient loading (Table 2; Figs. 4B, 5C), reduced belowground biomass of seagrasses (Table 1; Fig. 5A), but increased above to belowground biomass ratio in the conditions of nutrient loading (Table 2; Fig. 5B). Our findings are in accordance with those of previous studies (e.g. Pérez-Lloréns and Niell, 1993; Terrados et al., 1999). Shoot:root (including rhizome) ratio in Zostera noltii was higher in the high organic muddy sediments in Palmones River estuary, Spain (Pérez-Lloréns and Niell, 1993). Terrados et al. (1999) also found some bigger seagrasses were negatively affected by the addition of organic matter to the sediment in terms of decreased Thalassia hemprichii shoot density and Z. marine leaf growth. Enhanced organic matter sedimentation can cause anoxia and sediment sulphide intrusions into the plants (Holmer and Bondgaard, 2001; Olivé et al., 2009; Pérez et al., 2007). High organic matter content may enhance the process of nitrate transformed into ammonium (Seitzinger, 1988), consequently increase ammonium toxicity to seagrasses (Govers et al., 2014), therefore negatively affect seagrasses growth.

Sediment anoxia can promote seagrass growth inhibition and mortality by increasing the oxygen demand of the sediment with the addition of organic matter (Han and Liu, 2014; Terrados et al., 1999), because carbon translocation from leaves to roots is stopped due to 
relevant metabolic adaptation for controlling carbon losses under anaerobic conditions (Zimmerman and Alberte, 1996). Sulphide, one of the main causes of the regressions of the seagrsses, is known to have inhibitory effects on plant growth, although seagrasses demonstrate some tolerance at least to short-term sulphide exposure (Erskine and Koch, 2000; Koch and Erskine, 2001). Nitrogen fixation in seagrass sediments is dependent on photosynthates exuded by seagrass roots (Welsh et al., 1996, 1997). Nutrient enrichment increased seagrasses demand for carbon to support metabolic processes in anaerobic sediments with organic matter addition (Burkholder et al., 1992; Irlandi et al., 2004; Lee and Dunton, 1999), which may explain the negative effects of organic matter loading on seagrass growth during sediment-nutrient enrichment.

\section{Acknowledgements}

This study was funded by the Natural Science Foundation of China (41576117, 41106099, 41306108, 41406128), the Netherlands Organisation for Scientific Research (No. 843.10.003), the Strategic Priority Research Program of the Chinese Academy of Sciences (XDA11020702), the Key Research Program of Chinese Academy of Sciences (KZZDEW-14), and the Ministry of Science and Technology Project Foundation (2014FY210600).

\section{References}

Ågren, G.I., 2004. The C:N:P stoichiometry of autotrophs-theory and observations. Ecol. Lett. 7, 185-191.

Apostolaki, E.T., Vizzini, S., Karakassis, I., 2012. Leaf vs. epiphyte nitrogen uptake in a nutrient enriched Mediterranean seagrass (Posidonia oceanica) meadow. Aquat. Bot. 96, 58-62.

ART (Aquaculture Research Team in Administration of Fisheries, Ministry of Agriculture of the People's Republic of China), 2006e. Research on main aquaculture methods in China. Chin. Aquacult. 2,11-13 (in Chinese).

Baker, M.A., Valett, H.M., Dahm, C.N., 2000. Organic carbon supply and metabolism in a near-stream groundwater ecosystem. Ecology 81, 3133-3148.

Balata, D., Piazzi, L., Nesti, U., Bulleri, F., Bertocci, I., 2010. Effects of enhance loads of nutrients on epiphytes on leaves and rhizomes of Posidonia oceanica. J. Sea Res. 63, 173-179.

Barko, J.W., Smart, R.M., 1983. Effects of organic matter additions to sediment on the growth of aquatic plants. J. Ecol. 71, 161-175.

Billen, G., Garnier, J., 2007. River basin nutrient delivery to the coastal sea: assessing its potential to sustain new production of non-siliceous algae. Mar. Chem. 106, 148-160.

Borum, J., Pedersen, O., Greve, T.M., Frankovich, T.A., Zieman, J.C., Fourqurean, J.W., Madden, C.J., 2005. The potential role of plant oxygen and sulphide dynamics in die-off events of the tropical seagrass, Thaliassia testudinum. J. Ecol. 93, 148-158.

Bouwman, A.F., Bierkens, M.F.P., Griffioen, J., Hefting, M.M., Middelburg, J.J., Middelkoop, H., Slomp, C.P., 2013. Nutrient dynamics, transfer and retention along the aquatic continuum from land to ocean: towards integration of ecological and biogeochemical models. Biogeoscience 10, 1-22.

Brix, H., Lyngby, J.E., 1985. Uptake and translocation of phosphorus in eelgrass (Zostera marina). Mar. Biol. 90, 111-116.

Brun, F.G., Hernández, I., Vergara, J.J., Pérez-Lloréns, J.L., 2002. Assessing the toxicity of ammonium pulses to the survival and growth of Zostea noltii. Mar. Ecol. Prog. Ser. 225, 177-187.

Brun, F.G., Olivé, I., Malta, E.M., Veragara, J.J., Hernández, I., Pérez-Loréns, J.L., 2008. Increased vulnerability of Zostera noltii to stress caused by low light and elevated ammonium levels under phosphate deficiency. Mar. Ecol. Prog. Ser. 365, 67-75.

Bulthuis, D.A., Woelkerling, W.J., 1981. Effects of in situ nitrogen and phosphorus enrichment of the sediments on the seagrass Heterozostera tasmanica (Martens ex Aschers.) den Hartog in Western Port, Victoria, Australia. J. Exp. Mar. Biol. Ecol. 53, 193-207.

Burkholder, J.M., Mason, K.M., Glasgow Jr., H.B.G., 1992. Water-column nitrate enrichment promotes decline of eelgrass Zostera marina: evidence from seasonal mesocosm experiments. Mar. Ecol. Prog. Ser. 81, 163-178.

Burkholder, J.M., Tomasko, D.A., Touchette, B.W., 2007. Seagrasses and eutrophication. J. Exp. Mar. Biol. Ecol. 350, 46-72.

Campbell, J.E., Yarbro, L.A., Fourqurean, J.W., 2012. Negative relationships between the nutrient and carbohydrate content of the seagrass Thalassia testudinum. Aquat. Bot. 99, 56-60.

Cancemi, G., Falco, G.D., Pergent, G., 2003. Effects of organic matter input from a fish farming facility on a Posidonia oceanica meadow. Estuar. Coast. Shelf Sci. 56, 961-968.

Day Jr., J.W., Hall, C.A.S., Kemp, W.M., Yáñez-Arancibia, A., 1989. Estuarine Ecology. Wiley, New York, USA.

Delgado, O., Ruiz, J., Pérez, M., Romero, J., Ballesteros, E., 1999. Effects of fish farming on seagrass (Posidonia oceanica) in a Mediterranean bay: seagrass decline after organic loading cessation. Oceanol. Acta 22, 109-117.

Dong, C.L., Qi, X.L., Liu, J., 2007. Food habits of whooper swan in winter at the Tian'e hu of Rongcheng. Chin. J. Zoo. 42 (6), 53-56 in Chinese with English abstract.

Duarte, C.M., 1990. Seagrass nutrient content. Mar. Ecol. Prog. Ser. 67, 201-207.
Erskine, J.M., Koch, M., 2000. Sulfide effects on Thalassia testudinum carbon balance and adenylate energy charge. Aquat. Bot. 67, 275-285.

Fourqurean, J.W., Zieman, J.C., 1992. Phosphorus limitation of primary production in Florida Bay: evidence from C:N:P ratios of the dominant seagrass Thalassia testudinum. Limnol. Oceanogr. 37, 162-171.

Fourqurean, J.W., Duarte, C.M., Kennedy, H., Marbà, N., Holmer, M., Mateo, M.A. Apostolaki, E.T., Kendrick, G.A., Krause-Jensen, D., McGlathery, K.J., Serrano, O., 2012. Seagrass ecosystems as a globally significant carbon stock. Nat. Geosci. 5 505-509.

Fourqurean, J.W., Moore, T.O., Fry, B., Hollibaugh, J.T., 1997. Spatial and temporal variation in C:N:P ratios, $\delta^{15} \mathrm{~N}$, and $\delta^{13} \mathrm{C}$ of eelgrass Zostera marina as indicators of ecosystem processes, Tomales Bay, California, USA. Mar. Ecol. Prog. Ser. 157, 147-157.

Froelich, P.N., 1988. Kinetic control of dissolved phosphate in natural rivers and estuaries: a primer on the phosphate buffer mechanism. Limnol. Oceanogr. 33, 649-668.

Govers, L.L., de Brouwer, J.H.F., Suykerbuyk, W., Bouma, T.J., Lamers, L.P.M., Smolders, A.J.P., van Katwijk, M.M., 2014. Toxic effects of increased sediment nutrient and organic matter loading on the seagrass Zostera noltii. Aquat. Toxicol. 155, 253-260.

Gray, J.S., Wu, R.S., Or, Y.Y., 2002. Effects of hypoxia and organic enrichment on the coastal marine environment. Mar. Ecol. Prog. Ser. 238, 249-279.

Han, Q.Y., Liu, D.Y., 2014. Macroalgae blooms and their effects on seagrass ecosystems. J. Ocean Univ. China 13 (5), 791-798.

Han, Q.Y., Bouma, T.J., Brun, F.G., Suykerbuyk, W., van Katwijk, M.M., 2012. Resilience of Zostera noltii to burial or erosion disturbances. Mar. Ecol. Prog. Ser. 449, 133-143.

Han, Q.Y., Soissons, L.M., Bouma, T.J., van Katwijk, M.M., Liu, D.Y., 2016. Combined nutrient and macroalgae loads lead to response in seagrass indicator properties. Mar. Pollut. Bull. 106, 174-182.

Hauxwell, J., Cebrian, J., Baliela, I., 2001. Macroalgal canopies contribute to eelgrass (Zostera marina) decline in temperate estuarine ecosystems. Ecology 82, 1007-1022

Hemminga, M., Duarte, C.M., 2000. Seagrass Ecology. Cambridge University Press, Cambridge, United Kingdom.

Hessing-Lewis, M.L., Hacker, S.D., Menge, B.A., Rumrill, S.S., 2011. Context-dependent eelgrass-macroalgae interactions along an estuarine gradient in the pacific northwest, USA. Estuar. Coasts 34, 1169-1181.

Holmer, M., Bondgaard, E.J., 2001. Photosynthetic and growth response of eelgrass to low oxygen and high sulfide concentrations during hypoxic events. Aquat. Bot. 70, 29-38

Holmer, M., Kristensen, E., 1996. Seasonality of sulfate reduction and pore water solutes in a marine fish farm sediment: the importance of temperature and sedimentary organic matter. Biogeochemistry 32, 15-39.

Holmer, M., Frederiksen, M., Møllegaard, H., 2005. Sulfur accumulation in eelgrass (Zostera marina) and effect of sulfur on eelgrass growth. Aquat. Bot. 81, 367-379.

Huntington, B.E., Boyer, K.E., 2008. Effects of red macroalgal (Gracilariopsis sp.) abundance on eelgrass Zostera marina in Tomales Bay, California. USA. Mar. Ecol. Prog. Ser. 367, $133-142$.

Invers, O., Kraemer, G.P., Pérez, M., Romero, J., 2004. Effects of nitrogen addition on nitrogen metabolism and carbon reserves in the temperate seagrass Posidonia oceanica. J. Exp. Mar. Biol. Ecol. 303, 97-114.

Irlandi, E.A., Orlando, B.A., Biber, P.D., 2004. Drift algae-epiphyte-seagrass interactions in a subtropical Thalassia testudinum meadow. Mar. Ecol. Prog. Ser. 279, 81-91.

Koch, M.S., Erskine, J.M., 2001. Sulfide as a phytotoxin to the tropical seagrass Thalassia testudinum: interactions with light, salinity and temperature. J. Exp. Mar. Biol. Ecol. 266, 81-95.

Korom, S.F., 1992. Natural denitrification in the saturated zone: a review. Water Resour. Res. 28, 1657-1668.

La Nafie, Y.A., de los Santos, C.B., Brun, F.G., Mashoreng, S., van Katwijk, M.M., Bouma, T.J. 2013. Biomechanical response of two fast-growing tropical seagrass species subjected to in situ shading and sediment fertilization. J. Exp. Mar. Biol. Ecol. 446, 186-193.

La Nafie, Y.A., de los Santos, C.B., Brun, F.G., van Katwijk, M.M., Bouma, T.J., 2012. Waves and high loads jointly decrease survival and separately affect morphological and biomechanical properties in the seagrass Zostera noltii. Limnol. Oceanogr. 57 (6) 1664-1672.

Lee, K.S., Dunton, K.H., 1997. Effect of in situ light reduction on the maintenance, growth and partitioning of carbon resources in Thalassia testudinum banks ex König. J. Exp. Mar. Biol. Ecol. 210 (1), 53-73.

Lee, K.S., Dunton, K.H., 1999. Inorganic nitrogen acquisition in the seagrass Thalassid testudinum: development of a whole-plant nitrogen budget. Limnol. Oceanogr. 44 1204-1215.

Lee, K.S., Short, F.T., Burdick, D.M., 2004. Development of a nutrient pollution indicator using the seagrass, Zostera marina, along nutrient gradients in three New England estuaries. Aquat. Bot. 78, 197-216.

López, N.I., Duarte, C.M., Vallespinós, F., Romero, J., Alcoverro, T., 1995. Bacterial activity in seagrass (Posidonia oceanica) sediments. J. Exp. Mar. Biol. Ecol. 187, 39-49.

Martínez-Crego, V.A., Alcoverro, T., Romero, J., 2008. Selection of multiple seagrass indicators for environmental biomonitoring. Mar. Ecol. Prog. Ser. 361, 93-109.

Mateo, M.A., Romero, J., 1997. Detritus dynamics in the seagrass Posidonia oceanica: elements for an ecosystem carbon and nutrient budget. Mar. Ecol. Prog. Ser. 151, 43-53.

Miao, W.W., Jiang, M., 2007. Environmental impacts and sustainable development of aquaculture in China. J. Agro-Environ. Sci. 26, 319-323 (in Chinese with English abstract).

Nixon, S.W., 1995. Coastal marine eutrophication: a definition, social causes, and future concerns. Ophelia 41, 199-219.

Nixon, S.W., Ammerman, J.W., Atkinson, L.P., Berounsky, V.M., Billen, G., Boicourt, W.C., Boynton, W.R., Church, T.M., Ditoro, D.M., Elmgren, R., Garber, J.H., Giblin, A.E., Jahnke, R.A., Owens, N.J.P., Pilson, M.E.Q., Seitzinger, S.P., 1996. The fate of nitrogen and phosphorus at the land-sea margin of the North Atlantic Ocean. Biogeochemisty $\underline{35,141-180 .}$ 
Olivé, I., García-Sánchez, M.P., Brun, F.G., Vergara, J.J., Pérez-Lloréns, J.L., 2009. Interactions of light and organic matter under contrasting resource simulated environments: the importance of clonal traits in the seagrass Zostera noltii. Hydrobiologia 629, 199-208.

Orth, R.J., Carruthers, T.J.B., Dennison, W.C., Duarte, C.M., Fourqurean, J.W., Heck Jr., K.L. Hughes, A.R., Kendrick, G.A., Kenworthy, W.J., Olyarnik, S., Short, F.T., Waycott, M. Williams, S., 2006. A global crisis for seagrass ecosystems. Bioscience 56, 987-996.

Penhale, P.A., Wetzel, R.G., 1983. Structural and functional adaptations of eelgrass (Zostera marina L.) to the anaerobic sediment environment. Can. J. Bot. 61, 1421-1428.

Peralta, G., Bouma, T.J., van Soelen, J., Pérez-Lloréns, J.L., Hernández, I., 2003. On the use of sediment fertilization for seagrass restoration: a mesocosm study on Zostera marina L. Aquat. Bot. 75, 95-110.

Pérez, M., García, T., Invers, O., Ruiz, J.M., 2008. Physiological responses of the seagrass Posidonia oceanica as indicators of fish farm impact. Mar. Pollut. Bull. 56, 869-870.

Pérez, M., Invers, O., Ruiz, J.M., Frederiksen, M.S., Holmer, M., 2007. Physiological responses of the seagrass Posidonia oceanica to elevated organic matter content in sediments: an experimental assessment. J. Exp. Mar. Biol. Ecol. 344, 149-160.

Pérez-Lloréns, J.L., Niell, F.X., 1993. Seasonal dynamics of biomass and nutrient content in the intertidal seagrass Zostera noltii Hornem. from Palmones River estuary. Spain. Aquat. Bot. 46, 49-66.

Peterson, B.J., Stubler, A.D., Wall, C.C., Gobler, C.I., 2012. Nitrogen-rich groundwater intrusion affects productivity, but not herbivory, of the tropical seagrass Thalassid testudinum. Aquat. Biol. 15, 1-9.

Pregnall, A.M., Smith, R.D., Kursar, T.A., Alberte, R.S., 1984. Metabolic adaptation of Zoster marina (eelgrass) to diurnal periods root anoxia. Mar. Biol. 83, 141-147.

Rabalais, N.N., Turner, R.E., Díaz, R.J., Justic, D., 2009. Global change and eutrophication of coastal waters. ICES J. Mar. Sci. 66 (7), 1528-1537.

Romero, J., Lee, K.S., Mateo, M.P.M., Alcoverro, T., 2006. Nutrient dynamics in seagrass ecosystem. In: Larkum, A.W.D. (Ed.), Seagrass: Biology, Ecology and Conservation. Springer, the Netherlands, pp. 227-254

Ruiz-Halpern, S., Macko, S.A., Fourqurean, J.W., 2008. The effects of manipulation of sedimentary iron and organic matter on sediment biogeochemistry and seagrasses in a subtropical carbonate environment. Biogeochemistry 87, 113-126.

Seitzinger, S.P., 1988. Denitrification in freshwater and coastal marine ecosystems: ecological and geochemical significance. Limnol. Oceanogr. 33 (4), 702-724.

Seitzinger, S.P., Nixon, S.W., 1985. Eutrophication and the rate of denitrification and $\mathrm{N}_{2} \mathrm{O}$ production in coastal marine sediments. Limnol. Oceanogr. 30 (6), 1332-1339.

Short, F.T., 1983. The seagrass, Zostera marina L.: plant morphology and bed structure in relation to sediment ammonium in Izembek lagoon, Alaska. Aquat. Bot. 16, 149-161

Short, F.T., Wyllie-Echeverria, S., 1996. Natural and human-induced disturbance of seagrasses. Environ. Conserv. 23, 17-27.

Short, F.T., Polidoro, B., Livingstone, S.R., Carpenter, K.E., Bandeira, S., Bujang, J.S., Calumpong, H.P., Carruthers, T.J.B., Coles, R.G., Dennison, W.C., Erftemeijer, P.L.A. Fortes, M.D., Freeman, A.S., Jagtap, T.G., Kamal, A.H.M., Kendrick, G.A., Kenworthy, W.J., La Nafie, Y.A., Nasution, I.M., Orth, R.J., Prathep, A., Sanciangco, J.C., van Tussenbroek, B., Vergara, S.G., Waycott, M., Zieman, I., 2011. Extinction risk assessment of the world's seagrass species. Biol. Conserv. 144, 1961-1971.

Smith, R.D., Dennison, W.C., Alberte, R.S., 1984. Role of seagrasses photosynthesis in root aerobic processes. Plant Physiol. 74, 1055-1058.

Soissons, L.M., Han, Q.Y., Li, B.Q., van Katwijk, M.M., Ysebaert, T., Herman, P.M.J., Bouma, T.J., 2014. Cover versus recovery: contrasting responses of two indicators in seagrass beds. Mar. Pollut. Bull. 87, 211-219.

Sterner, R.W., Elser, J.J., 2002. Ecological Stoichiometry-the Biology of Elements from Molecules to the Biosphere. Princeton University Press, Princeton, USA.

Stitt, M., 1997. The flux of carbon between the chloroplast and the cytoplasm. In: Dennis, D.T., Turpin, D.H., Lefebvre, D.D., Layzell, D.B. (Eds.), Plant Metabolism. Longman Scientific \& Technical, Singapore, pp. 382-400.
Stumm, W., Morgan, J.J., 1996. Aquatic Chemistry: Chemical Equilibria and Rates in Natural Waters. 3rd edition. Wiley-Interscience, New York, USA.

Terrados, J., Duarte, C.M., Kamp-Nielsen, L., Agawin, N.S.R., Gacia, E., Lacap, D., Fortes, M.D., Borum, J., Lumbanski, M., Greve, T., 1999. Are seagrass growth and survival constrained by the reducing conditions of the sediment? Aquat. Bot. 65, 175-197.

Thursby, G.B., Harlin, M.M., 1982. Leaf-root interaction in the uptake of ammonia by Zostera marina. Mar. Biol. 72, 109-112.

Thursby, G.B., Harlin, M.M., 1984. Interaction of leaves and roots of Ruppia maritime in the uptake of phosphate, ammonia and nitrate. Mar. Biol. 83, 61-67.

Touchette, B.W., 1999. Physiological and Developmental Responses of Eelgrass (Zostera marina L.) to Increases in Water-Column Nitrate and Temperature (Ph.D. Dissertation) North Carolina State University, Raleigh, NC, USA.

Touchette, B.W., Burkholder, J.M., 2000. Overview of the physiological ecology of carbon metabolism in seagrasses. J. Exp. Mar. Biol. Ecol. 250, 169-205.

Udy, J.W., Dennison, W.C., 1997a. Physiological responses of seagrasses used to identify anthropogenic nutrient inputs. Mar. Freshw. Res. 48, 605-614.

Udy, I.W., Dennison, W.C., 1997b. Growth and physiological responses of three seagrass species to elevated sediment nutrients in Moreton Bay, Australia. J. Exp. Mar. Biol. Ecol. 217, 253-277.

van Katwijk, M.M., van der Welle, M.E.W., Lucassen, E.C.H.E.T., Vonk, J.A., Christianen, M.J.A., Kiswara, W., Hakim, I.I., Arifin, A., Bouma, T.J., Roelofs, J.G.M., Lamers, L.P.M., 2011. Early warning indicators for river nutrient and sediment loads in tropical seagrass beds: a benchmark from a near-pristine archipelago in Indonesia. Mar. Pollut. Bull. 62, 1512-1520.

van Katwijk, M.M., Vergeer, L.H.T., Schmitz, G.H.W., Roelofs, J.G.M., 1997. Ammonium toxicity in eelgrass Zostera marina. Mar. Ecol. Prog. Ser. 157, 159-173.

Villazán, B., Brun, F.G., Jiménez-Ramos, R., Pérez-Lloréns, J.L., Vergara, J.J., 2013. Interaction between ammonium and phosphate uptake rates in the seagrass Zostera noltii. Mar. Ecol. Prog. Ser. 488, 133-143.

Waycott, M., Duarte, C.M., Carruthers, T.J.B., Orth, R.J., Dennison, W.C., Olyarnik, S., Calladine, A., Fourqurean, J.W., Heck Jr., K.L., Hughes, A.R., Kendrick, G.A., Kenworthy, W.J., Short, F.T., Williams, S., 2009. Accelerating loss of seagrasses across the globe threatens coastal ecosystems. PNAS 106, 12377-12381.

Welsh, D.T., Bourgués, S., de Wit, R., Herbert, R.A., 1996. Seasonal variations in nitrogenfixation (acetylene reduction) and sulphate-reduction rates in the rhizosphere of Zostera noltii: nitrogen fixation by sulphate-reducing bacteria. Mar. Biol. 4, 619-628.

Welsh, D.T., Bourgués, S., de Wit, R., Auby, I., 1997. Effect of plant photosynthesis, carbon sources and ammonium availability on nitrogen fixation rates in the rhizosphere of Zostera noltii. Aquat. Microb. Ecol. 12, 285-290.

Wood, N., Lavery, P., 2000. Monitoring seagrass ecosystem health-the role of perception in defining health and indicators. Ecosyst. Health 6, 134-148.

Worm, B., Reusch, T.B.H., 2000. Do nutrient availability and plant density limit the seagrass colonization in the Baltic Sea? Mar. Ecol. Prog. Ser. 200, 159-166.

Worm, B., Reusch, T.B.H., Lotze, H.K., 2000. In situ nutrient enrichment: methods for marine benthic ecology. Int. Rev. Hydrobiol. 85, 359-375.

Zhang, B., Du, Y.Y., Chen, Y.W., Zhang, L., 2012. Denitrification in sediments of typical rivers in Taihu Basin. Acta Sci. Circumst. 32 (8), 1866-1873 (in Chinese with English abstract).

Zhang, X.M., Zhou, Y., Liu, P., Wang, F., Liu, B.J., Liu, X.J., Xu, Q., Yang, H.S., 2014. Temporal pattern in the bloom-forming macroalgae Chaetomorpha linum and Ulva pertusa in seagrass beds, Swan Lake lagoon, North China. Mar. Pollut. Bull. 89, 229-238.

Zimmerman, R.C., Alberte, R.S., 1996. Effect of light/dark transition on carbon translocation in eelgrass Zostera marina seedlings. Mar. Ecol. Prog. Ser. 136, 305-309. 